\title{
ASSESSMENT OF DRINKING WATER OF BHAKTAPUR MUNICIPALITY AREA IN PRE-MONSOON SEASON
}

\author{
Jasmine Diwakar*, Kayo Devi Yami** and Tista Prasai** \\ *Central Department of Environmental Science, Tribhuvan University, Kirtipur, Kathmandu, Nepal. \\ **Nepal Academy of Science and Technology, Khumaltar, Lalitpur, Nepal.
}

\begin{abstract}
The physico-chemical and microbiological analyses of the 116 water samples from four different sources namely, public tap, well, tube well and stone spout of Bhaktapur Municipality area were done following standard techniques for water sample collection and analyses set by the American Public Health Association (1998). The pH values of all water samples were found to lie within Nepal standard. Similarly 57(49.14\%), 9 (7.76\%), 56 (48.28\%) and 1(0.87\%) of water samples were found to exceed Nepal standard value for conductivity, turbidity, iron and chloride content respectively. Hardness content of all water samples were within the standard whereas 6 (5.17\%) samples crossed ammonia permissible level. The nitrate and arsenic content of all samples were found within permissible level. The bacteriological analysis of water samples revealed the presence of total coliform in 96 (82.76\%) of samples. So, the study has pointed out that the drinking water quality of city water supply has not been improved and traditional sources like stone spouts and tube well water are also not free from contamination. Such circumstances are responsible for spreading water borne outbreaks. The waterborne diseases are closely related with the conditions of living and environmental sanitation in the community. So, it can be effectively controlled by appropriate water management and safe disposal of excreta.
\end{abstract}

Key words: Arsenic; Coliform bacteria; Diseases; Iron and water quality.

\section{INTRODUCTION}

Changes in water quality are reflected in its physical, biologi$\mathrm{cal}$, and chemical conditions; and these in turn are influenced by physical and anthropogenic activities (ADB/ ICIMOD, 2006). Water quality has direct influence on public health. When water gets contaminated with various pathogenic as well as opportunistic microflora and toxic chemical compounds, it serves as the commonest vehicle of transmission of a number of infectious diseases. Unfortunately, over a billion people in the developing world do not have access to satisfactory water supply. The WHO has estimated that up to $80 \%$ of all sickness and disease in the world is caused by inadequate sanitation, polluted or unavailability of water. The pollution of drinking water is responsible for a large number of mortalities and morbidities due to water-borne diseases like typhoid, cholera, dysentery, hepatitis as well a many protozoan and helminthic infestations (WHO, 1997). Diarrhoeal diseases are still recognized as a major problem for Nepalese children, being recorded as the second most prevalent diagnosis in out-patience services. Today $72 \%$ of the nationwide disease burden is related to poor quality of drinking water, and around 75 children die each day from diarrhoea alone (Sherpa, 2003). A report from HMG ministry of health $0.37 \%$ of people had typhoid, diarrhea $0.53 \%$, and jaundice and infective hepatitis $0.08 \%$ in Bhaktapur city. The chemical parameters of drinking water owe significant relation with the public health. Some chemicals, notably iron, ammonia, nitrates and recently arsenic are often included in routine monitoring of water supplies.

Bhaktapur Municipality is located at $27^{\circ} 36^{\prime}$ to $27^{\circ} 44^{\prime}$ North latitude and $85^{\circ} 21^{\prime}$ to $85^{\circ} 31^{\prime}$ East longitude. It contains sev- enteen wards. Bhaktapur, at 1,401 meter above sea level, spreads over and area of 6.88 square kilometers. This conch shaped historic city, Bhaktapur, lying at $12 \mathrm{~km}$ east of Kathmandu was founded in the $12^{\text {th }}$ century by King Ananda Dev Malla. People in Bhaktapur depend upon the well, stone spout, tube well and tap water to fulfill their needs and was target area for water sample collection and analysis. The study conducted area was one of the historical places of the Kathmandu valley. According the recent census, the population of Bhaktapur Municipality is 72,586. It consists of 87 stone spouts, 220 wells and 7207 piped lines (185 public tap).

Today, the need for clean water for drinking and sanitation has never been more pressing. The challenge is to create incentives in people to share human values of common responsibility not to pollute or overuse the water source (Johannessen, 2001). Clean water and sanitation are human rights, essential to life (Water aid, 2005). Studies on drinking water quality in Nepal was carried out by Bovier (1978), Sharma (1978), Leuenberger (1983), Adhikari et al (1986), Sharma (1986), ENPHO/DISVI (1990), WSSC (1990), ENPHO/DISVI (1991), Bottino et al (1991), Karmacharya et al (1991/92), ENPHO/ DISVI (1992), Dhaubadel (1992), K.C (1992), Lohani (1992), Pradhananga et al (1993), Ghimire (1996), Maharjan (1998), GRI/IBS (1999), Karmacharya and Pariyar (1999), NESS (1999), ENPHO (2000), Khadka (2001), Regmi (2001), Prasai (2002), Sharma et al (2002), Sundas (2002), Schaffner (2003), Upadhaya et al (2004), ENPHO (2005), JICA/ENPHO/MPW (2005), NGO FORUM (2006), Bajracharya (2007), DWSS (2007) and Jayana (2007). The present study intends to assess the physicochemical and microbiological quality of drinking water from different sources in Bhaktapur Municipality area.

Author for Correspondence: Jasmine Diwakar, Central Department of Environmental Science, Tribhuvan University, Kirtipur, Kathmandu, Nepal. Email: jasdiwa@gmail.com 
Table 1: Percentage of water samples above Nepal Standard $(\%)$

\begin{tabular}{|l|l|l|l|l|l|}
\hline Parameters & $\begin{array}{c}\text { Tap water } \\
\left(\mathrm{n}_{3}=31\right)\end{array}$ & $\begin{array}{c}\text { Well } \\
\left(\mathrm{n}_{3}=56\right)\end{array}$ & $\begin{array}{c}\text { Tube well } \\
\left(\mathrm{n}_{3}=4\right)\end{array}$ & $\begin{array}{c}\text { Stone spouts } \\
\left(\mathrm{n}_{1}=25\right)\end{array}$ & $\begin{array}{c}\text { Total } \\
(\mathrm{N}=116)\end{array}$ \\
\hline $\mathrm{pH}$ & 0 & 0 & 0 & 0 & 0 \\
\hline Conductivity & 0 & 98.21 & 0 & 8 & 49.14 \\
\hline Turbidity & 0 & 10.71 & 0 & 12 & 7.76 \\
\hline Hardness & 0 & 0 & 0 & 0 & 0 \\
\hline Chlonde & 0 & 1.79 & 0 & 0 & 0.87 \\
\hline Iron & 3.23 & 73.21 & 0 & 56 & 48.28 \\
\hline Nitrate & 0 & 0 & 0 & 0 & 0 \\
\hline Ammonia & 0 & 7.14 & 25 & 8 & 5.17 \\
\hline Arsenic & 0 & 0 & 0 & 0 & 0 \\
\hline
\end{tabular}

* Below Nepal Standard

\section{METHODOLOGY}

This study was conducted in Bhaktapur Municipality area from April 2007 to June 2007. One hundred and sixteen water samples were randomly collected from four different sources viz. public taps, wells, tube wells and stone spouts. Physicochemical and microbiological status was analyzed for assessment of drinking water quality. Analyses of the physico-chemical parameters were done by following APHA(1998). pH, Conductivity, ammonical-nitrogen, nitrate-nitrogen and arsenic of

Table 2: Sampling sites for public tap water showing total coliform count

\begin{tabular}{|c|c|c|c|}
\hline SN & $\begin{array}{c}\text { Sample } \\
\text { Water } \\
\text { code }\end{array}$ & Location & $\begin{array}{c}\text { Total } \\
\text { coliform } \\
\text { count }\end{array}$ \\
\hline 1 & $\mathrm{PTW}_{01}$ & Sakotha, Ward no,-11 & 0 \\
\hline 2 & $\mathrm{PTW}_{02}$ & Tibukchhe. Ward no.-8 & 0 \\
\hline 3 & $\mathrm{PTW}_{03}$ & Kolachhen, Ward no. -13 & 16 \\
\hline 4 & $\mathrm{PTW}_{04}$ & Tasimala, Ward no,-13 & 0 \\
\hline 5 & PTW $_{09}$ & Bangsagopal. Ward no.-16 & 0 \\
\hline 6 & $\mathrm{PTW}_{06}$ & Bangsagopal, Ward no.-16 & 0 \\
\hline 7 & $\mathrm{PTW}_{0 *}$ & Yalachhen, Sano Byasi, Ward no,-10 & 54 \\
\hline 8 & $\mathrm{PTW}_{\mathrm{OS}}$ & Yalachhen, Sano Byasi, Ward no,-10 & 0 \\
\hline 9 & $\mathrm{PTW}_{08}$ & Yalachhen. Sano Byasi, Ward no -10 & 0 \\
\hline 10 & $\mathrm{PTW}_{1 *}$ & Thulo Byasi, Ward no.-10 & 0 \\
\hline 11 & $\mathrm{PTW}_{11}$ & Thulo Byasi, Ward no.-10 & 0 \\
\hline 12 & PTW $_{12}$ & Chochhen, Mulachhen, Ward no.-9 & 0 \\
\hline 13 & $\mathrm{PTW}_{13}$ & Mahankali, Ward no.-5 & 101 \\
\hline 14 & $\mathrm{PTW}_{14}$ & Mahankali, Ward no,-5 & 1 \\
\hline 15 & PTW $_{19}$ & Mahankali. Ward no.-5 & 1 \\
\hline 16 & PTW $_{16}$ & Chochhen. Ward no.-9 & 0 \\
\hline 17 & $\mathrm{PTW}_{1 *}$ & Bolachhen, Ward no.-10 & 0 \\
\hline 18 & $\mathrm{PTW}_{18}$ & Sukuldhoka, Ward no,-8 & 0 \\
\hline 19 & $\mathrm{PTW}_{18}$ & Lalachhen. Ward no.-5 & 4 \\
\hline 20 & $\mathrm{PTW}_{3 *}$ & Yachhen, Ward no.-5 & 0 \\
\hline 21 & $\mathrm{PTW}_{21}$ & Yachhen. Ward no,-5 & 0 \\
\hline 22 & $\mathrm{PTW}_{3}$ & Dattatrya. Ward no. -3 & 0 \\
\hline 23 & $\mathrm{PTW}_{23}$ & Taulachhen. Suryamadhi, Ward no.-1 & 13 \\
\hline 24 & $\mathrm{PTW}_{24}$ & Twacha Gali, Suryamadhi, Ward no.-1 & 0 \\
\hline 25 & $\mathrm{PTW}_{25}$ & Innacho, Ward no,-6 & 0 \\
\hline 26 & $\mathrm{PTW}_{26}$ & Innacho, Ward no. -6 & 112 \\
\hline 27 & $\mathrm{PTW}_{27}$ & Golmadi, Ward no.-7 & 4 \\
\hline 28 & $\mathrm{PTW}_{2 \mathrm{~s}}$ & Chanchel, Golmadi, Ward no,-s & 0 \\
\hline 29 & PTW $_{39}$ & Hanumanghat, Ward no.-6 & 18 \\
\hline 30 & $\mathrm{PTW}_{3}$ & Degamana. Ward no.-16 & 0 \\
\hline 31 & $\mathrm{PTW}_{3 !}$ & Sallaghari, Ward no.-17 & $>300$ \\
\hline
\end{tabular}

Risk category as per microbial contamination ranges:

0 : in compliance with WHO guidelines

1-10: Low risk

10-100: Intermediate Risk

100-1000: high risk

More than 1000: very high risk water samples were recorded at the site during sampling period. Other parameters were analyzed in the Environment Laboratory of NAST. The samples were analyzed on the same day immediately after its delivery and always within 6 hours of collection. When immediate analyses was not possible, the samples were preserved at $4^{0} \mathrm{C}$. Total coliforms were enumerated by the membrane filtration (MF) technique as described by APHA (1998).

\section{RESULTS}

Out of one hundred and sixteen water samples (from public taps, wells, tube wells and stone spouts), The $\mathrm{pH}$ values of all water samples were found to lie within WHO guideline values. Similarly, 57 (49.14\%), 9 (7.76\%), 56 (48.28\%) and 1(0.87\%) of water samples were found to exceed Nepal standardfor conductivity, turbidity, iron and chloride content respectively. Hardness content of all water samples were within the guideline values whereas 6 (5.17\%) samples crossed ammonia permissible level. The nitrate and arsenic content of all samples were found within permissible level. These results compared with Nepal standard values for drinking water is as shown in Table 1.

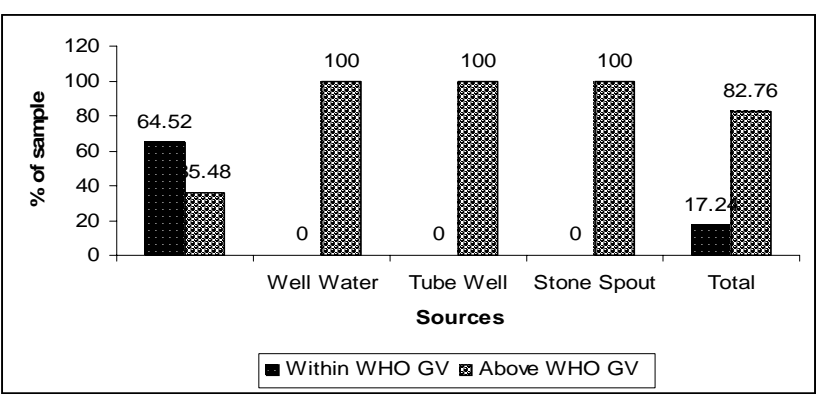

Fig 1: Total coliform count with respect to water sources

The bacteriological analysis of water samples revealed the presence of total coliform in $82.76 \%$ of samples (public tap $35.48 \%$, well $100 \%$, tube well $100 \%$ and stone spout $100 \%$ ). Of the total 31 public tap water samples, 20 were deprived of total coliform and rest were contaminated with total coliforms. The places including Kolachhen, Yalachhen, Mahankali, Lalachhen, Taulachhen, Innacho, Golmadi, Hanumanghat and Sallaghari were in the risk category (Table 2). Regarding wells, tube wells and stone spouts, water samples were found positive for total coliforms i.e.greater than $300 \mathrm{cfu}$.

\section{DISCUSSION}

This study assessed the physicochemical and bacteriological quality of various water sources. All water samples showed their $\mathrm{pH}$ values within the permissible level. $\mathrm{pH}$ is an operational water quality parameters and a large variety of pollutants such as discharges from industries containing detergents, heavy metals, bleaching materials, acids, alkalis etc affect the $\mathrm{pH}$ of receiving water. $\mathrm{pH}$ less than 7.0 may cause corrosion of metal pipes thereby releasing toxic metals like $\mathrm{Zn}, \mathrm{Pb}, \mathrm{Cd}$ and $\mathrm{Cu}$, etc. and higher than 8.0 adversely affect the disinfection process.

The conductivity of 57 (49.14\%) samples crossed the limit. Higher conductivity value was also seen in the studies of 
Karmacharya and Pariyar (1999), Prasai (2002) and Bajracharya (2007).It does not have a direct health effect. However, high conductivity most of the time is due to pollution. The Nepal standard for turbidity has been violated by 9 (7.76\%) of the samples. Previous studies by Karmacharya and Pariyar (1999), Khadka (2001), Prasai (2002), Schaffner (2003), Bajracharya (2007) and Jayana (2007) also revealed higher turbidity value in their water samples. Turbidity in water is caused by the presence of suspended and colloidal matter. Usually, water with high turbidity has offensive appearance, color, taste and odor. The main problem associated with turbidity is the microbiological quality since its presence can interfere with the detection of bacteria and viruses. Disinfection of water becomes less effective because the microorganisms are protected by the particles that cause turbidity.

The test result of hardness showed all water samples within the Nepal standard. Hardness of water is predominantly due to dissolved calcium and magnesium. Studies carried out so far do not reveal direct and conclusive health effect due to hardness in water $1(0.87 \%)$ of water samples contained high chloride content above permissible value. Chloride can be an indicator of pollution. Chloride in drinking water originates from natural sources, sewage and industrial effluents, urban runoff containing de-ionizing salts and saline intrusion. Usually the high concentrations of chloride in combination with nitrate or ammonium show that the water is contaminated by domestic sources. Concentrations of chloride were observed higher in wells, tube well and stone spouts than in public tap water. Studies of Ghimire (1996) and Jayana (2007) also found higher chloride content in their water sample.

Iron is one of the most abundant elements of the rocks and soil, ranking fourth by weight. All kinds of water have appreciable quantities of iron. Some of water samples 56 (48.28\%) exceeded the Nepal standard. High iron content was observed in the studies of ENPHO/DISVI (1990), ENPHO (1991), Bottino et al (1991), K.C (1992), Lohani (1992), Pradhananga et al (1993), Ghimire (1996), NESS (1999), Khadka (2001), Prasai (2002), Upadhaya et al (2004), JICA/ENPHO/MPW (2005), Bajracharya (2007) and Jayana (2007). Staining of laundry and plumbing may occur at concentrations above $0.3 \mathrm{mg} / \mathrm{liter}$. Iron also promotes undesirable bacterial growth ("Iron bacteria”) in water works and distribution system, resulting in the development of a slimy coating on the pipe. In addition to the natural sources of iron, corrosion of pipes, pumps, etc. can also increase its concentration in distribution systems. Although iron has got little concern as a health hazard but it is still considered as a nuisance in excessive quantities. When high concentrations of iron are absorbed, for example by haemochromatose patients, iron is stored in the pancreas, the liver, the spleen and the heart. This may damage these vital organs. Healthy people are generally not affected by iron overdose, which is also generally rare. It may occur when one drinks water with iron concentrations over 200 ppm.

In the present study the Nepal standard of ammonia (1.5mg/l) was violated by 6 (5.17\%) of the samples. Studies of K.C (1992), Pradhananga et al (1993), Karmacharya and Pariyar (1999), NESS (1999), ENPHO (2000), Khadka (2001), Sharma et al
(2002), Upadhaya et al (2004), JICA/ENPHO/MPW (2005), NGO FORUM (2006), Bajracharya (2007) and Jayana (2007) also found higher ammonia content in the ground water samples of Kathmandu valley. Presence of ammonia does not always mean that it is due to domestic pollution. High ammonia content in deep well can be due to the underlying intercalated layers of peat and lignite. Ammonia content in water may be harmful to health since it can be converted to nitrate. If only ammonia is present, pollution by sewage must be very recent. The occurrence of $\mathrm{NO}_{2}$ with ammonia indicates that some time has been lapsed since the pollution has occurred. If all the nitrogen is present in nitrate form, a long time has been passed after pollution, because water has purified itself and all nitrogenous matter has been oxidized. The presence of ammonia in ground waters is quite generally a result of natural degradation processes. Ammonia in higher concentration is toxic to man. The toxicity of ammonia increases with $\mathrm{pH}$ because at higher $\mathrm{pH}$ most of the ammonia remains in the gaseous form. The decrease in $\mathrm{pH}$ decreases the toxicity due to conversion of ammonia into ammonium ion which is much less toxic than the gaseous form.

Nitrate concentration was within the standard for all the water samples.

The ground water samples from all areas of Bhaktapur were found to be within the Nepal standard. In water, arsenic is found in the form of arsenite, arsenate and organic arsenicals which may result from mineral dissolution, industrial discharges or the application of pesticides. Continued consumption of arsenic contaminated water generally leads to numerous diseases, including skin cancer, gangrene, hematological poisoning, cardiovascular and nervous disorders.

In the present study, the microbiological analyses of water revealed the presence of total coliforms in 96 (82.76\%) of total samples i.e. the majority of water samples taken were found positive for total coliforms. Only 20 (64.52\%) tap water was total coliform count negative. Sourcewise distribution of coliform count clearly showed that wells 56 (100\%), tube wells $4(100 \%)$ and stone spouts 31 (100\%) crossed the Nepal standard and Nepal standard i.e. $0 \mathrm{cfu} / 100 \mathrm{ml}$.

The principal reason of the bacteriological pollution of drinking water are due to the use of unrepaired old pipeline systems for distribution, parallel arrangement of the drinking water pipeline with that of the drainage system and irregular supply of the drinking water in the pipeline. Beside that the contamination may be either due to the failure of the disinfections of the raw water at the treatment plant or because of the infiltration of contaminated water (sewage) through cross-connection and leakage points. All the natural water sources, such as wells, stone spouts and tube wells are neither treated nor protected properly. Thus, deteriorating water quality is the major problem and it has created serious threat to human health and environment. The quality of water has deteriorated due to poor management and no monitoring of water quality.

The greatest problem continues to be the microbial contamination of drinking water supplies. It is a tragedy that infants and young children are the innocent victims of the failure to 
make safe drinking water and basic sanitation services. In Nepal, morbidity and mortality rates from water borne disease are considered high particularly among children below the age of five. A report from HMG ministry of health 2004, in Bhaktapur, people suffered from typhoid $0.37 \%$, diarrhea $0.53 \%$, and jaundice and infective hepatitis $0.08 \%$. Improvements (safe water supply and of adequate means of sanitation) bring immediate and lasting benefits in health, dignity, education, productivity and income generation. The conservation of water sources is very important to provide safe water. As far as possible, water sources must be protected from contamination by human and animal waste, which can contain a variety of bacterial, viral, protozoan and helminthes parasites. The control of drinking water quality in distribution networks remains a major challenge in urban areas. Protection of sources, treatment and distribution management are all-critical strategies in maintaining and improving piped water supplies. Prevention of the disease is therefore a matter of providing safe drinking water.

\section{CONCLUSION}

The present study disclosed the physicochemical and bacteriological contamination of different water sources in Bhaktapur municipality area in pre-monsoon season. Besides coliform contamination, the concentration of chloride, iron and ammonia were high in some of the water samples.

\section{ACKNOWLEDGEMENTS}

Acknowledgements are due to Nepal Academy of Science and Technology, Khumaltar for the laboratory facilities and instruments provided for this work.

\section{REFERENCES}

ADB/ICIMOD. 2006. Environmental Assessment of Nepal, Emerging Issues and Challenges. Asian Development Bank and International Centre for Integrated Mountain Development, Kathmandu. pp: 55-64.

Adhikari, R., S. K. Rai, B.M. Pokhrel and J. B. Khadka. 1986. Bacteriological Study of Drinking Water of Kathmandu Valley, Journal of Institute of Medicine. 8(3): 313-376.

APHA. 1998. Standards methods for the examination of water and wastewater. $20^{\text {th }}$ edition. American Public Health Association, Washington, DC.

Bajracharya, A. M., K.D. Yami, T. Prasai, S. R. Basnyat and B. Lekhak. 2007. Assessment of drinking water quality of Kathmandu metropolitan areas. Nepal journal of science and technology 8: 113-118.

Bottino, A., A. Thapa, A. Scantoline, B. Ferino, S. Sharma and M. T. Pradhananga. 1991. Pollution in the Water Supply System of Kathmandu City. Journal of Nepal Chemical Society. 10:33-44.

Bovier, E.K. 1978. First report on Millipore Bacteriological Water Tests, Rural Water Supply Noted “A” Gandaki Zone. LDD. UNICEF/ SATA, Pokhara. Nepal.

Dhaubadel, M. S. 1992. Study in drinking water quality of Bhaktapur a dissertation submitted to Central Department of Zoology, Tribhuvan University, Kirtipur, Nepal.

DoHS. 2004/2005. Annual report. Ministry of Health and Population, Department of Health services, Kathmandu, Nepal.
DWSS. 2007. Summary of known Arsenic Occurrence in Ground water in Nepal, Government of Nepal, National Arsenic Steering Committee, Maharajgung, Kathmandu, Nepal.

ENPHO/DISVI. 1990. Water quality testing in Illam. Environment and Public Health Organization and DISVI International Co-operation, Kathmandu

ENPHO/DISVI. 1991. A case Study on Gastroenteritis Epidemic in the Mid-Western Region of Nepal (Rukum and Dang). ENPHO/DISVI Italian International Cooperation, Kathmandu.

ENPHO/DISVI. 1991. Drinking water of Pokhara, A Case Study, Report submitted to GTZ/UDLE. Environment and Public Health Organization and DISVI International Co-operation, Kathmandu.

ENPHO/DISVI. 1991. Water quality testing in Siraha. Environment and Public Health Organization and DISVI International Co-operation, Kathmandu

ENPHO/DISVI. 1992. Monitoring of Kathmandu City water supply with reference to chlorination and microbiological quality. Environment and Public Health Organization and DISVI International Co-operation, Kathmandu

ENPHO. 1999.. Monitoring of Groundwater Quality in the Kathmandu valley, Nepal. Institutional Strengthening of the ministry of population and environment (ADB TA 2847-NEP) ENPHO. Pp: 25-29.

ENPHO. 2000. Kathmandu City Looking through the Eyes of ENPHO, Environment and Public Health Organization a Decade, $10^{\text {th }}$ Anniversary Souvenir. Kathmandu: ENPHO

ENPHO. 2001. A Diagnostic Survey Report on Drinking Water Quality and Sanitation Situation in the UNICEF's project area Kavre, Parsa and Chitwan, ENPHO. pp: vi.

ENPHO. 2003. Water for the future, world water day-2003, ENPHO Magazine, ENPHO, Thapagaon, New Baneshwor, Kathmandu. pp: 23.

ENPHO. 2005. Groundwater Quality surveillance in Kathmandu and Lalitpur municipality area, JICA/ MPPW. /ENPHO, Kathmandu.

Ghimire, M.K. 1996. Ground Water Quality Analysis in Patan Area. a dissertation submitted Central Department of Meteorology, Tribhuvan University, Kirtipur, Kathmandu, Nepal.

Global Resources Institute and the International Buddhist Society. 1999. Water Survey, Water Testing, and Testing of Solar Disinfection in Lumbini, Nepal, Global Resources Institute. Eugene, Oregon 97440, USA. (www.grilumbiniwatersupply.htm)

ICIMOD/MoEST/UNEP. 2007. Kathmandu Valley Environmental Outlook. International Centre for Integrated Mountain Development, Ministry of Environment, Science and Technology and United Nations Environmental Programmes, Kathmandu. pp. 1-10, 57-72.

JICA/ ENPHO/MPPW. (2005. Groundwater quality surveillance in Kathmandu and Lalitpur Municipality areas. JICA expert office at MPPW, Singhdurbar and Environment and Public Health Organization, Kathmandu.

Jayana, B. L. 2007. Assessment of Drinking water Quality of Madhyapur Thimi and Study of Antibacterial Effect of Lime Juice Against Bacterial Isolates. A dissertation submitted to Central Department of Microbiology, Tribhuvan University, Kirtipur, Nepal.

Johannessen, A. 2001. Human Values in Water Education; Application in Water Classroom, Human Values in Water Education, Creating a New Water- Use Ethic in African Cities. United Nations Human Settlement Programmes, UN-HABITAT. pp: 34

Joshi, D. R. and M. P. Baral. 2004. Chemical and Microbial Quality of Kathmandu Valley. Abstracts of $4^{\text {th }}$ National Conference on Science and Technology. March 23-26, pp: 252. 
Karmacharya, A. P. and C. B. Pariyar. 1999. Quality of Groundwater in the Kathmandu Valley, Nepal. Environment and Agriculture. Biodiversity Agriculture and Pollution in south Asia, 2001. In: Proceedings of International Conference on Environment and Agriculture. November 1-3, 1998, Kathmandu. (Eds: Jha, P.K., Baral, S. R., Karmacharya, S.B., Lekhak, H. D., Lacoul, P and Baniya, C.B.). Ecological Society (ECOS), Kathmandu, Nepal. pp: 499-502.

Karmacharya P. A., R. K. Shrestha and S. Shakya. 1991/1992. Monitoring of the Kathmandu city water supply with reference to chlorination and microbiological quality, Environment and Public Health Organization, Kathmandu

K.C., G. 1992. Studies on Drinking Water Quality of Shivapuri Main Source to its Panipokhari Reservoir and Treatment Plants and the Distribution Systems of Kathmandu Valley, a dissertation submitted for degree in Zoology, Central Department of Zoology, Tribhuvan University, Kirtipur, Kathmandu, Nepal.

Leuenberger, H. 1983. Trinkwasserqualitat in 13 ausgewahlten Anlagen dos CWSS- Pragrammes in Pokhara Nepal Ausgefuhrt Von H. L in der Praktimumszeit Vol II September 19, Dez 1983. NADEL: Nachdiplomastudium for Entwicklungslander.

Lohani, A. 1992. Study in Drinking Water Quality of Koteshwor Area, A dissertation submitted to Central Department of Zoology, Tribhuvan University, Kirtipur, Kathmandu, Nepal.

Maharjan, M. 1998. Assessment of Groundwater Quality and Study of Antibiotic Resistance and Oligodynamic Action against Some Isolated Enteric Bacteria, a dissertation submitted to Central Department of Microbiology, Tribhuvan University, Kirtipur, Kathmandu, Nepal.

Maharjan, M and A. P. Sharma. 2000. Bacteriological Quality of Groundwater in Urban Patan and Antibiotic Sensitivity Against Isolated Enteric Bacteria, Journal of Nepal Medical Association; Vol. 39: 269-274.

Nakayama, M. 1998. Water: the $21^{\text {st }}$ century's oil. Work in Progress 15: 2 .

NESS. 1999. Environmental Mapping- Madhyapur Thimi Municipality. NESS. pp 2-19.

NGO FORUM. 2006. Traditional Stone Spouts. Enumeration, Mapping and water quality (five municipal area of the Kathmandu Valley 2006). NGO FORUM for urban water and sanitation. New Baneshwor, Kathmandu. pp:6- 47.

Pradhananga, T.M., A. Thapa, U. Sharma, R. R. Shahi and S. Shrestha. 1993. Water Quality Monitoring of Stone Taps of Pashupati Area,
Journal of Nepal Chemical Society. 12: 55-62

Prasai, T. 2002. Drinking water quality assessment of Kathmandu valley and antibacterial property of medicinal plants against enteric bacteria isolated from water, a dissertation submitted to Central Department of Microbiology, Tribhuvan University, Kirtipur, Nepal.

Prasai, T., D. R. Joshi, B. Lekhak and M. P. Baral. 2007. Microbiological analysis of drinking water of Kathmandu valley. Scientific World 5:112-114.

Regmi, P. 2001. Water quality analysis of stone taps (spouts) of Kathmandu city, a dissertation submitted to Central Department of Meteorology and Hydrology, Tribhuvan University, Kirtipur, Nepal.

Schaffner, M. 2003. Drinking Water Quality Assessment and Improvement in the Jhikhu Khola Catchment, Nepal. Department of Geography, University of Bern, Bern Germany), Publication Gewaesserkunde, No. 281.

Sharma, A.P. 1978. The quality of Drinking water in Kathmandu, Journal institutes. 1: 15-22.

Sharma, A.P. 1986. Study of some chemicals and bacteriological aspect of drinking water in Kathmandu, a report submitted to national committee for man and biosphere, Kathmandu. pp: 15-22.

Sharma, S., R. Bajracharya, B. K. Sitaula and J. Merg. 2005. Water Quality in the Central Himalaya, Asian Institute of Technology, Current Science, Thailand. 89(5):782.

Sherpa, M. G. 2003. Message in a bottle. Water for the future, World Water Day-2003. Environment and Public Health Organization, Kathmandu. pp: 23.

Sundas, S. 2002. Drinking Water Problem in Kathmandu District, a dissertation submitted to Central Department of Economics, Tribhuvan University, Kirtipur, Nepal.

Thapa, S. 2002. Assessment of biological contamination and water borne helminthic parasites in drinking water sources on ward no. 20 KMC, a dissertation submitted to Central Department of Zoology, Tribhuvan University, Kirtipur, Nepal.

Water Aid. 2005. Water Aid 2004/05, Annual Review. Water Aid, Prince Consort House.

UNEP. 2001. Nepal: State of the environment. United Nations Environment Programmes, Kathmandu.

WHO. 1997. World Health Forum Bulletin, the ten biggest killers in the world. World Health Organization pp: 18 